\title{
Brexit: 100 Years in the Making
}

\author{
Martin Conway
}

The departure of the United Kingdom from the European Union set in motion by the referendum of 2016 has become the great accident of our age; an aberrant and illogical project, and one which, for historians above all, flies in the face of the dominant logics of globalisation, European integration and democratic convergence. Seen in those terms, it is at best a spasm provoked by the negligence of a UK political elite who had become too removed from the preoccupations of the population - as in France in 1958 perhaps - and at worst, an act of antidemocratic thuggery which has opened the way to a range of populist adventures that recall the latter years of the Weimar Republic.

Much of that may, alas, be true, even if the ascendancy of this interpretation, and its alarmist points of comparison, also tells us a little about the dominant values and social composition of the historical profession. However, it is also worth exploring the other side of this process. Divorces tend to happen between two parties, and it is interesting to reflect on what Brexit reveals about the attitudes of the European states. In particular, it focuses attention on the faultline which exists, and has long existed, between the United Kingdom and the neighbouring states of the European continent. One of the shortcomings of much of the instant history written in the aftermath of the referendum has been its understandable tendency to focus rather too exclusively on the UK side of the equation. But, if one brings in the European side, Brexit might appear to be more historically comprehensible and less exclusively British in its dynamics.

Placed in the longer perspective of relations between the United Kingdom and its European neighbours over the century since the signing of the peace treaties at the end of the First World War, Brexit does not appear so anomalous. If many of the key sites of memory of the UKEuropean relationship in the twentieth century are ones of engagement - in the trenches of the First World War, at Versailles, on the beaches of Normandy and, finally, in the symbolism of the UK's entry into the European Communities in 1973 - historians all know that these moments were discontinuous, and on the whole untypical. British policy makers from the 1920s to the present day have displayed a consistent tendency to choose other options over that of a close engagement with Europe. Imperial preference, the perceived need to avoid continental military entanglements, the lure of the Anglo-American partnership and the strange delusions generated by the centrality of London to the financial institutions of an increasingly global capitalism, were all ways of thinking that drew British elites, of both right and left, away from the sustained engagement with Europe which the outcome of the First World War might have been expected to have ordained.

The reasons for this British choice are complex, and all the more so given the way in which the lives of many members of the British ruling elite have been intertwined - through their formative experiences, family ties and emotional entanglements - with the European continent during the twentieth century. It was not that these British decision makers did not understand Europe; they lived with it, all too intimately. However, the other side of this process also demands examination. Why, to put it perhaps too crudely, were the leaders of Europe - however one might define that entity - willing to live without the United Kingdom?

Of course, this might seem to be the wrong way to pose the question. Europe did not choose Brexit; and, if it seems doomed to endure it, this is a consequence of the conjunctural impotence 
of the EU institutions during the decline of the Merkel and Hollande regimes. Rather than responding positively to the efforts of the Cameron government to negotiate a new relationship with the EU, the Council fell back on reiterating the outmoded core principles of the Union, notably free movement of peoples and free trade. There is much that is of value in such an analysis, and historians will no doubt be eager to integrate Brexit into the larger story of the loss of momentum of the European project, and more mundanely of the key political institutions of the EU, from the early 2000s onwards. Yet, there also seems to be more to this story than the declining fortunes of the EU. Brexit occurred in the context of a weakness of European leadership, but its broader plausibility arose from the widely held perception of the UK as semidetached from Europe.

How far one chooses, as historians, to trace the origins of this European mentality is a matter of taste. Some might look to the Reformation, or to the wars of the Revolutionary and Napoleonic eras; others might focus on the divergent state trajectories generated by imperialist expansion in the nineteenth century. But, for those of us who are contemporary historians, this seems to be a story made in the formative decades of the mid-twentieth century. However one chooses to relate the peacemaking after the First World War, and the early optimism of the League of Nations, it is difficult to see it as anything other than a period of open-ended possibilities, when the integration of a newly activist UK into the affairs of Europe seemed as likely as any other scenario. British attitudes undoubtedly had changed, but so too had those of European leaders, who were much more willing to regard the UK as a key player in the nascent post-war order. That was true, most obviously, of Stresemann and Briand, but also of Mussolini and many of the revisionist German nationalists who went along with the Nazi regime in its early years. For them, as for the economists and military strategists of the era, the UK mattered and had become a European power.

And yet, somewhere along the road, this ceased to be the case. The division was neither sudden nor irreversible. Yet, for all of the grand rhetoric voiced by the 'Remain' advocates in the referendum campaign, it was striking how limited they were in their references to the events of the mid-twentieth century. The broadbrush truths of the UK's engagement with Europe in two world wars, and the sacrifices it endured to preserve or remake peace in Europe, amounted to something less than a durable UK-European alliance. That owed much of course to the European leaders who came to the fore in the 1930s. If appeasement was a rather clumsy attempt on the part of the UK to mediate a new peace settlement in Europe, it hardly met with a favourable response from its European interlocutors, who from the Spanish Civil War onwards launched themselves into wars of ideological, national and ethnic conflict in which the UK was often the enemy, and rarely more than the most circumstantial of allies. Enforced exile in London during the war years provoked mixed reactions among Europe's many pretenders to post-war power. Admiration of British resilience was accompanied by resentments born of military and financial dependence, as well as a sense of the fundamental differentness of the United Kingdom. If Anglophilia was, at least at a personal level, a legacy of that wartime experience of England on the part of some European leaders, it was one which rested on difference rather than similarity.

There was therefore no relaunch of UK-European collaboration after 1945. On the European side the priorities were the recovery of national independence and economic viability, the tools for which were available more readily from the United States than from an over-extended and financially exhausted United Kingdom. More profoundly, too, the Western European elites who came to the fore in the later 1940s did not look instinctively to the United Kingdom. The anti-communist priorities of the early Cold War presented an obvious common foe, but anticommunism in Europe was always focused primarily on the enemy within rather than on confronting the Soviet Union. Moreover, the new European form of democracy which took shape after 1945 defined itself almost by its distance from the UK model. In place of the polarised 
theatre of Westminster, European political leaders created a multi-party structure, based on the sharing of power at the local and national levels. Many, especially on the socialist left in Europe, had initially looked to the Beveridge Plan for inspiration, but the plural and para-statal welfare structures that came into existence in post-war Western Europe were very different from those of the NHS. In the economic sphere, too, the statist priorities of the Labour government of 1945 symbolised by the nationalisation of key industrial sectors - were rejected by European governments, who were more inclined to combine corporatist institutions and economic planning with the retention of private enterprise. Above all, Christian democracy - which by the end of the 1950s had become the dominant vehicle of centre-right politics in much of Western Europe encouraged an intra-European convergence which by instinct and policy avoided a close engagement with the United Kingdom.

The new Western-defined Europe which took shape after 1945, and which acquired its institutional structure through the Treaty of Rome, therefore felt little need to reach out to the United Kingdom. There were of course exceptions: in matters of defence, the Western European states continued to rely through NATO on the waning resources of the UK armed forces; but, even in the many wars of European decolonisation, the United Kingdom and the European states operated - Suez excepted - in largely separate spheres, each constructing their own post-colonial hinterlands. Above all, the motor of rapid economic growth, and the concomitant social changes, gave a new character, and territorial shape, to Western Europe. The national economies of Europe gave way to common markets, transnational ownership and shared businesses practices; while mass migration within Western Europe, and from its southern borderlands, invested European societies with a more mobile and fluid population. The UK was indisputably part of these trends. European populations migrated to the UK, especially from southern Europe, and from the 1960s onwards the UK, and more especially British popular culture as conveyed by music, fashion and the pervasive new medium of television, became a magnetic focus of attraction and tourist destination for European populations, especially of the younger generations.

This bottom-up Anglo-European rapprochement did not, however, acquire a parallel political momentum. For all of the evident sincerity of Edward Heath in bringing the UK into the European Communities in 1973, there was from the outset a certain awkwardness to the new relationship. The history of the first generation of British elites who invested, professionally and personally, in the project of Europe has often been hidden behind the much more familiar narrative of UK political and institutional reluctance to engage with the forward leap of European integration from the 1980s onwards. But, though British figures became a prominent presence in European decision making, there remained a reluctance on the part of European elites to allow their Europe to be modified - economically, politically, juridically - by the new British presence. As more recent member states of the European Union have also had occasion to discover, the institutions of Brussels, and the principal nation states which stand behind them, have some rather old maps of Europe in their minds. The motor of Franco-German collaboration through the era of Kohl, Mitterrand and Delors felt that it had little need of the UK; and, in particular, the project of a common European currency and subsequently the European Central Bank, rested on understandings of financial responsibility very different from those of the global institutions of the City of London. In response, Thatcher drew her own conclusions, but what was striking was the failure of her successors, notably Blair - surely the most instinctively European prime minister of the UK during the twentieth century - to integrate an influential British voice into European decision making.

Brexit, therefore, was a death foretold, and one which, for all of their expressions of regret, European leaders, in the political, administrative and economic spheres, feel able to cope with. The more pressing challenges, they sense, lie elsewhere, and in particular on frontiers other than that in Ireland. In that respect they are behaving much as many of their predecessors did 
over the last hundred years. During the twentieth century the British have been Europe's military and diplomatic allies, the providers of refuge and a source of ideas, as well as economic and financial partners; but, to turn a phrase of Thatcher to a very different purpose, they were never one of us. 